\title{
ENHANCING THE WASH OIL ANTIFOULING ACTION IN A CRACKED GAS COMPRESSION (CGC) SYSTEM.
}

(Received 23 April 2004; Revision Accepted 23 July 2004)

\begin{abstract}
Pure grade samples from operational wash oil (used in cracked gas compression unit), light cycle oil, heavy residue and heavy diesel oil were obtained. Miscible blend samples of ratio 1:1 were also obtained from wash oil/light cycle oil and wash oil/heavy residue. These samples were subjected to characterization and the following quality parameters were measured, namely: aromatic content, specific gravity, gum content and distillation range.

The results obtained from Tables 2 and 3 for wash oil/heavy residue blend, sample $E$, showed $44.10,0.951$, 6.72 and $184.2^{\circ} \mathrm{C}-223.2^{\circ} \mathrm{C}$ as aromatic content, specific gravity, gum content and distillation range respectively. These quality parameters were seemingly consistent with the standard for wash oil (Table 3 ). Enhanced antifouling and dispersing action were observed to be adequate in the wash oil / heavy residue blend, sample $E$ probably due to its high aromatic content. Heavy residue, sample $\mathrm{C}$ was therefore seen as most suitable blending solvent for the operational wash oil, sample A.
\end{abstract}

KEY WORDS: Gas Compression, Polymeric Fouling, Antifoulant, Quality Parameters and wash oil.

\section{INTRODUCTION}

Cracked gas compression system may consist of three or more compressors casings driven by single or double extraction - condensing steam turbines (Bangerter, 1990). In Nigeria, Eleme Petrochemicals Company Limited (EPCL) is one major industry that utilizes the multistage Process Gas Compression (PGC) system (also called olefins plant). The plant employ's radial centrifugal compression exclusively, in five stages and takes multi component "Natural Gas Liquid (NGL)" as major feedstock to the plant with the sole aim of producing pure grades olefins. This feed is treated in the oracking furnaces sub-units such as the NGL fractionators, water quench system, process gas compression and cold sections (Okeh, 2000 and Jerkins, 1997).

The process gas compression is muiti-stage and requires multiple compressors provided with inter-stage coolers and after stage cooler at the compression discharge (Figure 1). The coolers are heat exchangers that removes the heat of compression from the gas feed and reduces its temperature to approximately that at the compression intake (safe limit) (Coker, 1994). Another use of coolers is to reduce the actual volume of gas floving to the high pressure cylinders, while the knockout pot (separator) after the intercooler is installed to remove the condense liquid and protect the down stream compressor from possible accumulation and fouling (Coker, 1994).

In the interludes of inlet and outlet gas compression system, elevated temperatures abound (Table 1), such that at $90^{\circ} \mathrm{C}$ and above, foulants may be found deposited on the compressors casings, bearings, blades, seals, rotors and discharge lines (Figure 2). Other location areas of fouling may include inter-stage cooler shells and lubes, cooling water sides and knockout drums plates and trays (Bangerter and Kranz (1993), and Barnard, 2000).

In anticipation of an emerging fouling, the EPCL introduces wash oil inline to serve as antifoulant or dispersant with the aim of inhibiting possible polymers formation by decomposing peroxide radicals probably formed, interrupting the chain forming reaction by reacting with radicals formed and dispersing existing insoluble polymers by carrying them out of the system (Bangerter, 1990 and Wiehe, 2001).

Inspite of the introduction of wash oil into the cracked gas compression system, fouling keep reoccurring probably due to either longer run lengths of compressors, or inadequate aromatic content in the wash oil or oxygen intake via compressors sealing oil, hence there is the need to upgrade the operational wash oil, as a part of a local contribution to its functionality. To achieve this, blend samples from wash oil and selected hydrocarbon solvents would be obtained and subjected to characterizaticı on the basis of aromatic content, specific gravity, gum content and distillation range as quality parameters. The experimental scheme would be based on ASTM standards.

\section{Effects of Polymeric Fouling on the CGC System}

Polymeric fouling affects the cracked gas compression (CGC) system in a number of ways, first it reduces compressors efficiency's by increasing the energy consumption, and secondly, it causes compressors vibrations which may lead to reduction in throughput and run length (Bangerter, 1990). Fouling deposits found in the interstage coolers tubes and shells would reduce heat transfer by raising the inlet temperature of the next stage. This is capable of increasing the fouling potential of the next stage and decreasing the efficiency. Also, pressure drop across the cooler may increase as well, by reducing the inlet pressure and efficiency of the next stage (Bangerter and Kranz, 1993). 


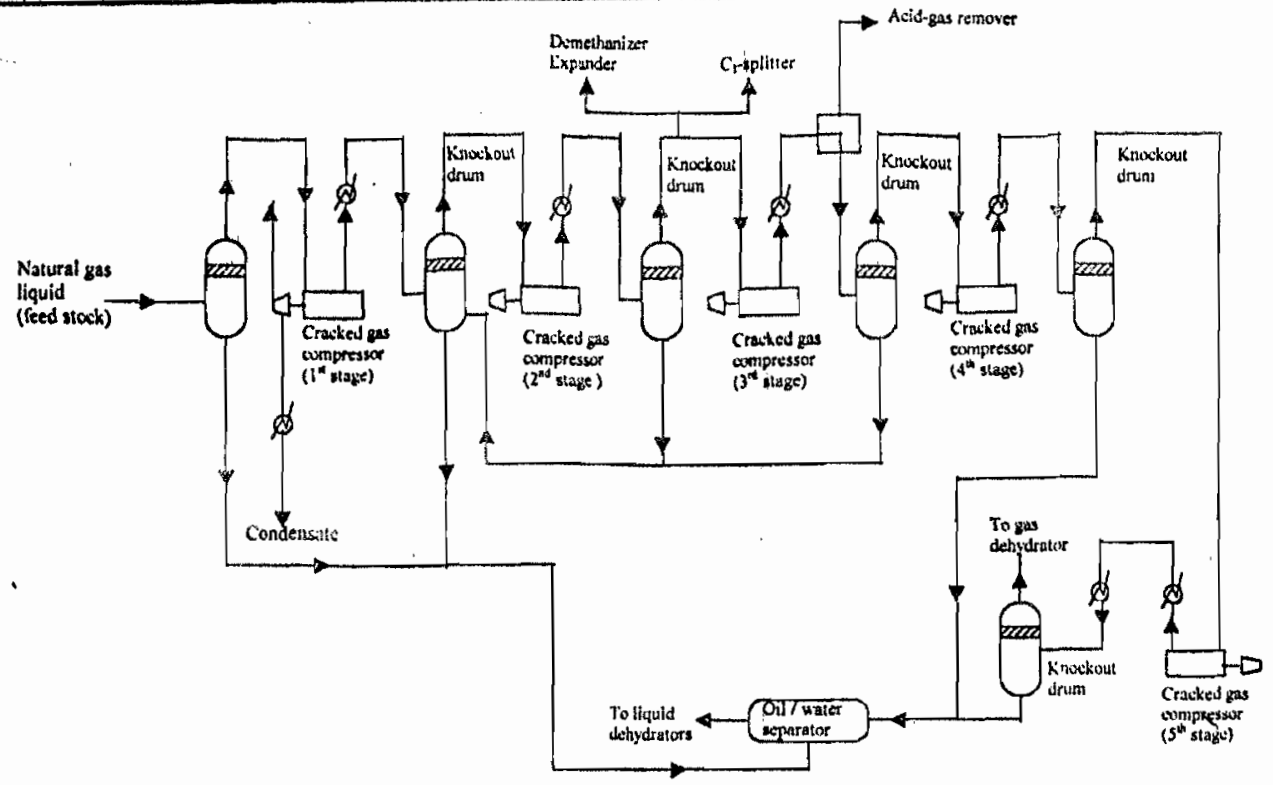

Figure 1: Cracked Gas Compression and Liquid Removal System (Bangerter, 1990)

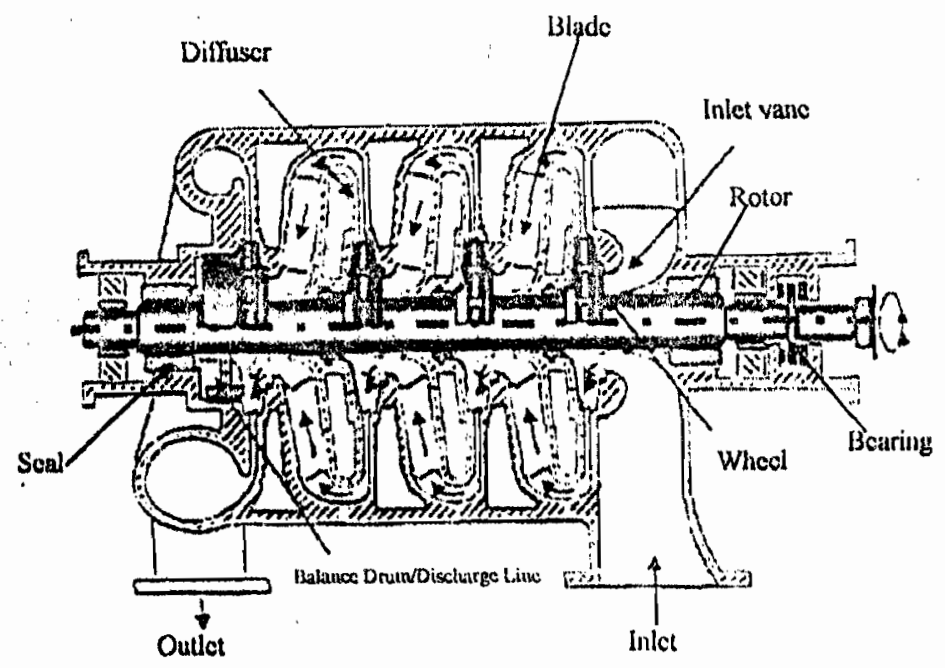

Figure 2: Fouling Location Lites in centrifugal compressar (Coker, 1998)

Table 1: Cracked Gas Compressors Operating Conditions

\begin{tabular}{|c|c|c|c|c|c|}
\hline STAGE & 1 & 2 & 3 & 4 & 5 \\
\hline $\begin{array}{l}\text { Flow rates } \\
\left(\mathrm{Nm}^{3} / \mathrm{h}\right)\end{array}$ & 91786 & 42577 & 18701 & 9154 & 5606 \\
\hline $\begin{array}{l}\text { Inlet / out } \\
\text { Pressures } \\
\left(\mathrm{kg} / \mathrm{cm}^{2}\right) \mathrm{A}\end{array}$ & $\begin{array}{l}1.13471 \\
2.967\end{array}$ & $\begin{array}{l}2.750 / \\
6.415\end{array}$ & $\begin{array}{l}6.1901 \\
12.960\end{array}$ & $\begin{array}{l}12.6011 \\
22.088\end{array}$ & $\begin{array}{l}20.8721 \\
41.534\end{array}$ \\
\hline $\begin{array}{l}\text { Inlet / Out } \\
\text { Temperatures } \\
\left({ }^{\circ} \mathrm{C}\right)\end{array}$ & $35.3 / 100$ & $35.6 / 100$ & 37.3198 & $37.3 / 83$ & $36.8 / 96$ \\
\hline
\end{tabular}

\section{Mechanisms of Polymeric Fouling Formation}

Polymeric fouling in cracked gas compression (CGC) systems arises from the liquid feedstock which contains appreciable quantities of highly reactive diolefins (mainly butadiene and isoprene), and subjected to polymerization at elevated temperatures and in the presence of oxygen. This reaction follow a radical chain mechanism initiated by thermal homolysis and peroxides (Hercules, 2000). The mechanisms follow a sequence of three steps: Initiation, propagation and termination. The initiation is associated with oxygen, with some of the feedstock forming peroxides (Free radical). Consequently, diolefin monomers are activated radically forming a growing polymer chain. Propagation proceeds by subsequent addition of more monomers while termination is brought about by combination or disproportionation. 
In addition, the absence of oxygen may compel some of the feed stock components to form unoxygenated free radicals, which subsequently may engage in polymerization resulting also in the deposit of fouling (Hercules, 2000). A step by step account is presented as follows:

\section{Initiation}
$\mathrm{R}-\mathrm{H}+\mathrm{O}_{2}$
$\stackrel{\text { metal }}{\longrightarrow}$
$\mathrm{ROOH}$

ROOH Thermal

$\stackrel{\text { Homolysis }}{\longrightarrow} \quad \underset{\text { Free radical }}{\longrightarrow} \quad$ (oxyciencitad)

$R-H \quad \begin{array}{c}\text { Thermal } \\ \text { Homolysis }\end{array} \quad R^{*}+H^{*}$ (uncixygenatio $)$

$\mathrm{ROO}^{\circ}+\underset{\text { (butadiene) }}{\mathrm{H}_{2} \mathrm{C}=\mathrm{CH}-\mathrm{CH}}=\mathrm{CH}_{2} \longrightarrow \underset{\text { (growing chain) }}{\mathrm{ROO}}-\underset{\text { ( }}{\mathrm{CH}_{2}-\mathrm{CH}=\mathrm{CH}_{2} \mathrm{C}^{\circ}}$

and

$\mathrm{R}^{*}+\mathrm{H}_{2} \mathrm{C}=\underset{\text { (butadiene) }}{\mathrm{CH}-\mathrm{CH}=\mathrm{CH}_{2}} \longrightarrow \underset{\text { (growing chain) }}{\mathrm{R}-\mathrm{CH}_{2}-\mathrm{CH}=\mathrm{CH}_{2}}$

\section{Propagation}

$\mathrm{ROO}-\mathrm{CH}_{2}-\mathrm{CH}=\mathrm{CH}-\mathrm{H}_{2} \mathrm{C}^{*}+\mathrm{nH}_{2} \mathrm{C}=\mathrm{CH}-\mathrm{CH}=\mathrm{CH}_{2}$

(Butadiene)

$\mathrm{ROO}-\left(\mathrm{CH}_{2}-\mathrm{CH}=\mathrm{CH} \mathrm{H} \mathrm{H}_{2}\right)_{\mathrm{n}} \mathrm{CH}_{2}-\mathrm{CH}=\mathrm{CH}-\mathrm{H}_{2} \mathrm{C}^{\circ}$ (growing chain)

and

$\mathrm{R}-\mathrm{CH}_{2}-\mathrm{CH}=\mathrm{CH}-\mathrm{H}_{2} \mathrm{C}^{\circ}+\mathrm{nH}_{2} \mathrm{C}=\mathrm{CH}-\mathrm{CH}=\mathrm{CH}_{2}$

$\mathrm{R}-\left(\mathrm{CH}_{2}-\mathrm{CH}=\mathrm{CH}-\mathrm{H}_{2} \mathrm{C}\right)_{n} \mathrm{CH}_{2}-\mathrm{GH}=\mathrm{CH}-\mathrm{H}_{2} \mathrm{C}^{\circ}$

(growing chain)

\section{Tormination}

The growing chain is killed by combination with hydrogen radical in the system

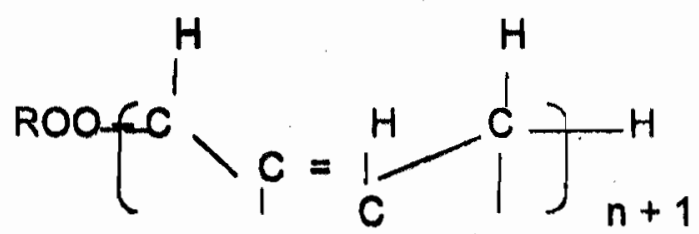

(Polymer (leposit)

H H

(Poly Butadiene)
H 


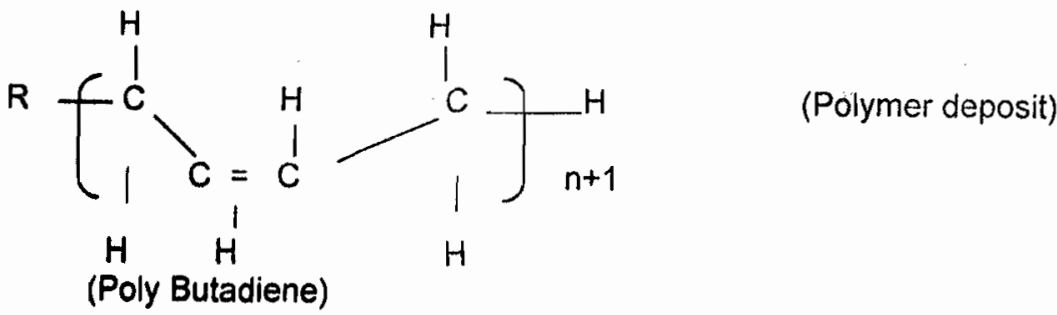

\section{Mechanisms of Polymeric Fouling Inhibition}

Wash oil is capable of inhibiting polymeric fouling by reacting with either the peroxy, alkyl or carbon centre propagating radicals and converting them to non-radical species or radicals with very low reactivity, in line with the mechanisms prescribed below (Hercules, 2000). It is worthy of note that the anti-radical and anti-propagation functionality of the wash oil is due mainly to its aromatic content.

\begin{tabular}{|c|c|c|}
\hline $\begin{array}{c}\mathrm{R}^{*}+ \\
\text { (Alkyl radical) }\end{array}$ & $\begin{array}{l}\text { Inhibitor } \\
\text { (wash oil) }\end{array}$ & $\begin{array}{l}R \text { - Inhibitor } \\
\text { (non-radical) }\end{array}$ \\
\hline (Alkoxyl radical) $^{\mathrm{RO}^{*}}+$ & $\begin{array}{l}\text { Inhibitor } \\
\text { (wash oil) }\end{array}$ & $\begin{array}{l}\text { RO - Inhibitor } \\
\text { (non-radical) }\end{array}$ \\
\hline $\begin{array}{c}R O O^{*}+ \\
\text { lkyl peroxy radical) }\end{array}$ & $\begin{array}{l}\text { Inhibitor } \\
\text { (wash oil) }\end{array}$ & $\begin{array}{l}\text { ROO - Inhibitor } \\
\text { (non-radical) }\end{array}$ \\
\hline
\end{tabular}

\section{EXPERIMENT AND METHOD}

The experiments involves the characterization of pure grade solvents from wash oil and other related hydrocarbon as well as their blends with wash oil, for the purpose of investigating their antifouling action which is strongly based on the following quality parameters: Aromatic content, Gum content, Distillation range and specific gravity.

\section{Equipment and Materials}

The equipment and apparatus used for this work are basically, Distillation machine, Gum content Machine, Unicam model gas chromatograph, 610 series (Figure 3), chemical balance, oven, hydrometer and thermometer. Others are cooler, bubbling chips, distillation flask, measuring cylinders $(100 \mathrm{ml}, 150 \mathrm{ml})$, desiccators, beakers and forceps.

Materials required are listed as follows: Pure grades wash oil, light cycle oil, Heavy residue and heavy diesel oil. Others are n-heptane, ice blocks and distilled water.

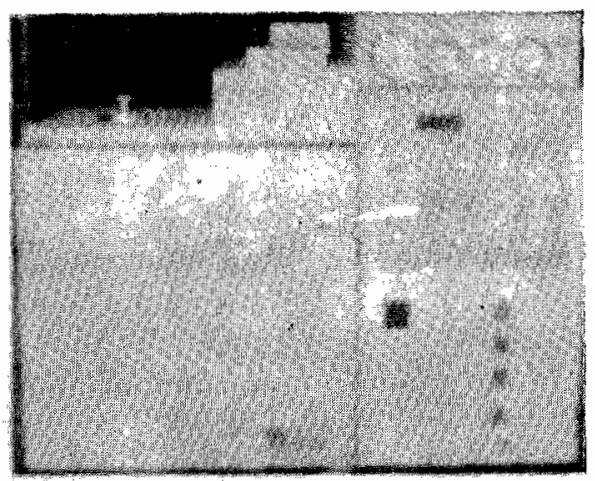

Nigure 3: Unicam Model Gas Chronatographlt (610 serles)

\section{Procedures}

Six samples were obtained from pure grades hydrocarbon solvents and its blends. They includes wash oil, light cycle oil, heavy residue, heavy diesel oil, and miscible blends from wash oil/heavy residue and wash oil/hint cycle oil. The samples were coded as $A, B, C, D, E$, and $F$ respectively, while a blend ratio of $1: 1$ was adopted. in 
samples were subjected to parameters evaluation in accordance with the American Society For Test And Materiais (ASTM) standards

\section{Distillation Range}

$100 \mathrm{ml}$ of sample was measured into a distillation flask, corked, with thermometer inserted, while bubbling clips were added into the flask to regulate liquid spills. The distillation flask was connected to the distillation machine for subsequent heating at regulated voltage depending on sample. A measuring cylinder placed under ice block was connected to the distillation flask for the purpose of collecting distillates

The temperature of first drop of condensate was recorded as initial boiling point (IBP) while that of the last drop of condensate was tagged final boiling point (FBP). The volume of condensate collected in the measuring cylinder was rated in percentage distillation as the distillation progresses while the associated temperature was recorded in the order of $5 \%, 10 \%, 30 \%$ to $95 \%$ distillation. These procedures were repeated for all samples and results obtained were at tolerance of \pm 0.001 .

\section{Specific Gravity}

$100 \mathrm{ml}$ of sample was transferred into a clean measuring cylinder without splashing so as to avoid the formation of air bubbies and ensures minimal evaporation. At sample temperature of $25^{\circ} \mathrm{C}$, a glass hydrometer was lowered into it and depressed to about two divisions and was thereafter released. Actual reading was taken from the hydrometer scale, when the hydrometer came to rest while floating freely and sample temperature had remained constant. These procedures were repeated for all samples.

Thus, actual scale reading from the hydrometer was the nearest scale division where the sample surface intersect the scale. Standard specific gravity reading was based on $60^{\circ} \mathrm{f}\left(15^{\circ} \mathrm{C}\right)$ sample temperature, tl'erefore, specific gravity values for all samples were corrected to standard using the ASTM tables for specific gravity at \pm 0.001 tolerance.

\section{Gum Content}

$10 \mathrm{ml}$ of sample each were measured into a $50 \mathrm{ml}$ beaker, and a tare (to serve as reference), while the initial weights of beaker and tare were already measured with a chernical balance and recorded as $W_{1}$ and $W_{2}$ respectively. Both tare and beaker were sealed and placed in metal cups of the evaporator chambers of the gum machine for 30 minutes at $160^{\circ} \mathrm{C}$ and $1 \mathrm{~atm}$. Both the tare and beaker were removed from the machine and cooled in desiccators for 2 hours.

$5 \mathrm{ml}$ of $n$-heptane was used to washed the sample in the beaker and tare, which stood for 10 minutes, later followed by. swirling and discarding. The beaker and tare were returned back into the gum machine for another 5 minutes heating process and subsequent cooling in desiccators followed for another 2 hours.

The final weights $W_{3}$ and $W_{4}$ for beaker and tare was measured respectively using a chemical balance. These procedures were repeated for all samples and the gum content was estimated empirically at tolerance limit of \pm 0.001 .

Gum content $=\left(W_{1}-W_{3}\right)+\left(W_{2}-W_{4}\right) \times 10,000$

\section{Aromatic content}

Unicam model gas chromatograph (610 series). was used for this measurement. Preconditional requirements for the analysis includes helium gas as carrier gas, flame ionization detector, $\mathrm{Al}_{2} \mathrm{O}_{3}$ and $\mathrm{KCl}$ (column materials). Set conditions were as follows: detector temperature, $250^{\circ} \mathrm{C}$; initial and final oven temperatures, $35^{\circ} \mathrm{C}$ and $200^{\circ} \mathrm{C}$ respectively and injection temperature, $200^{\circ} \mathrm{C}$.

At set conditions, $0.5 \mathrm{ml}$ of sample was first injected through the column for effective separation, on the basis of boiling point. The detector then predicts the concentration of ion of various components present in sample via the analog signals, which was converted into percentages with the aid of data sensor. These procedures were repeated for all samples at tolerance limit of \pm 0.0001 .

\section{RESULTS AND DISCUSSION}

Percentage Distillation and Distillation Range

Table 2 and Figure 4 showed the percentage distillation and the distillation range for all samples, and seems

Table 2: Distillation Ranges For Different Samples

\begin{tabular}{|l|l|l|l|l|l|l|}
\hline $\begin{array}{l}\text { Percentage } \\
\text { Distillation, } \\
\%\end{array}$ & $\begin{array}{l}\text { Sample A } \\
\text { (Wash oil), }{ }^{\circ} \mathrm{C}\end{array}$ & $\begin{array}{l}\text { Sample B } \\
\text { (light wash } \\
\text { oil), }{ }^{\circ} \mathrm{C}\end{array}$ & $\begin{array}{l}\text { Sample C } \\
\text { (Heavy } \\
\text { residue), }{ }^{\circ} \mathrm{C}\end{array}$ & $\begin{array}{l}\text { Sample D } \\
\text { (Heavy diesel } \\
\text { oil), }{ }^{\circ} \mathrm{C}\end{array}$ & $\begin{array}{l}\text { Sample E (wash } \\
\text { oil/heavy residue } \\
\text { blend), }{ }^{\circ} \mathrm{C}\end{array}$ & $\begin{array}{l}\text { Sample F (wash } \\
\text { oillight cycle oil } \\
\text { Blend), }\end{array}$ \\
\hline 5 & 104.8 & 223.3 & 175.4 & 284 & 184.2 & 191.6 \\
\hline 15 & 109.0 & 235.8 & 180.4 & 300 & 185.8 & 199.8 \\
\hline 30 & 129.80 & 250.3 & 194.2 & NE & 188.2 & 205.2 \\
\hline 519 & 163.0 & 260.0 & 205.4 & NE & 190.4 & 219.6 \\
\hline 70 & 187.2 & 276.3 & 227.2 & NE & 193.6 & 249.4 \\
\hline 90 & 203.9 & 294.5 & 278.0 & NE & 208.8 & 289.4 \\
\hline 95 & 219.0 & 302.2 & 290.2 & NE & 223.2 & 296.6 \\
\hline
\end{tabular}

$\mathrm{NE}=$ ivot Estimated 


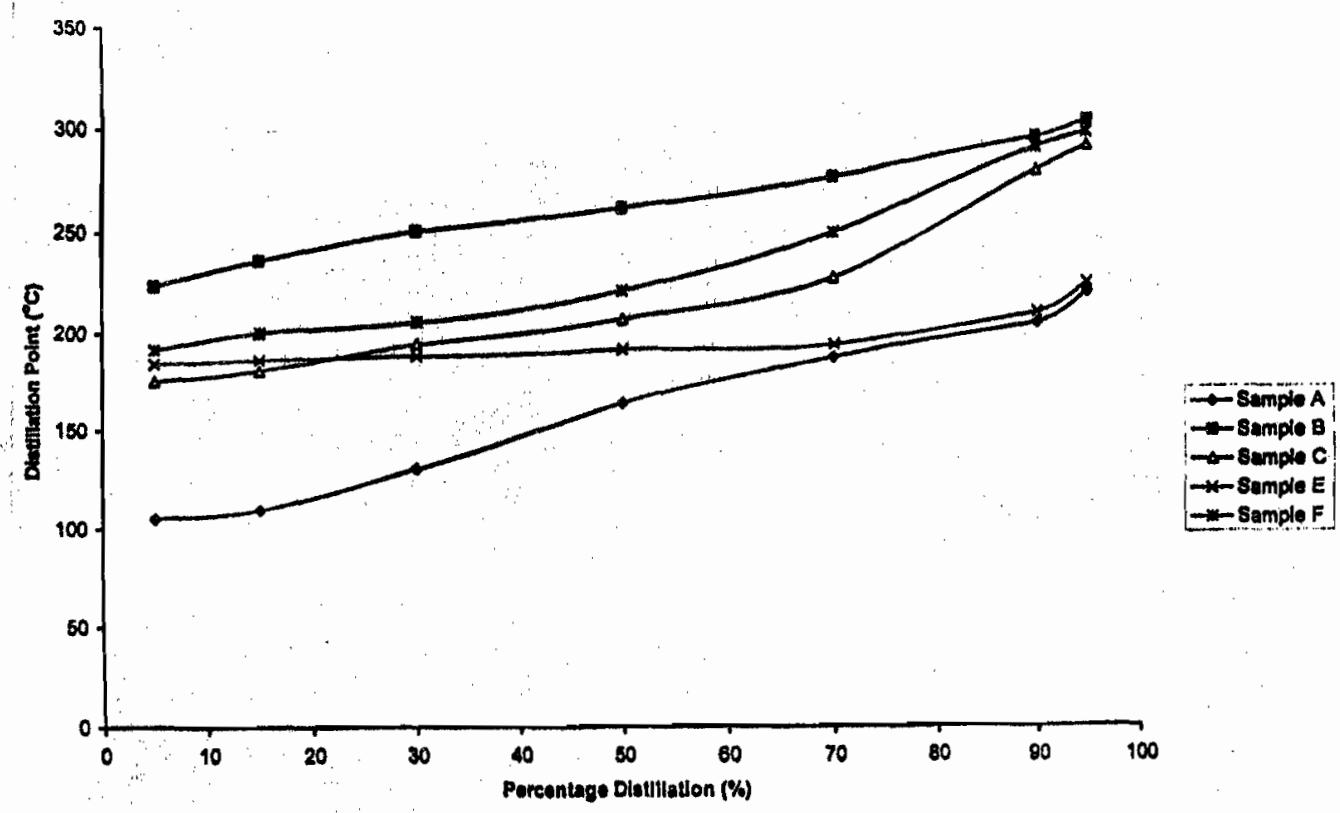

FIGURE 4: Plots of Diatliation Polnt againat percontage diatiliation

not to be too consistent with the standard for wash oil (Table 3). However, from a percentage distillation of $5 \%$ to $95 \%$, the wash oil, sample $A$ and light cycle oil, sample $B$ showed distillation ranges between $104.8^{\circ} \mathrm{C}-219^{\circ} \mathrm{C}$ and $223.3^{\circ} \mathrm{C}$ $-302.2^{\circ} \mathrm{C}$ respectively. Consequently, the wash oil, sample $A$ may be deduced to have the least distillation point at $50 \%$ djstillation and light cycle oil, sample B having the highest distillation point at $50 \%$ distillation, hence indicating a low and high retention time respectively.

The distillation range of the heavy diesel oil, sample $D$ could not be ascertained because of the inability to establish the distillation, hence is represented as NE (Not Estimated) from a distillation range of $30 \%-95 \%$. The distillation range observed for blend samples from wash oil/heavy residues, sample $E$ and wash oil/ light cycle oil, sample $\mathrm{F}$ are $184.2^{\circ} \mathrm{C}-223.2^{\circ} \mathrm{C}$ and $191.6^{\circ} \mathrm{C}-296.6^{\circ} \mathrm{C}$ respectively. This may be considered as moderate in terms of $50 \%$ distillation point and retention time.

Table 3: Quality Parameters Of Different Samples

\begin{tabular}{|c|c|c|c|c|c|c|c|}
\hline $\begin{array}{l}\text { Quality } \\
\text { Parameters }\end{array}$ & $\begin{array}{l}\text { Wash oil } \\
\text { (International } \\
\text { Standard) }\end{array}$ & $\begin{array}{l}\text { Sample A } \\
\text { (Wash oil, } \\
\text { operational) }\end{array}$ & $\begin{array}{l}\text { Sample B } \\
\text { (Light cycle } \\
\text { oil) }\end{array}$ & $\begin{array}{l}\text { Sample C } \\
\text { (Heavy } \\
\text { residue) }\end{array}$ & $\begin{array}{l}\text { Sample D } \\
\text { (Heavy diesel oil) }\end{array}$ & $\begin{array}{l}\text { Sample E } \\
\text { (Wash oil / } \\
\text { Heavy } \\
\text { residue } \\
\text { blend) }\end{array}$ & $\begin{array}{l}\text { Sample F } \\
\text { Wash oil/ } \\
\text { light cycle oil } \\
\text { blend) }\end{array}$ \\
\hline $\begin{array}{l}\text { Aromatic } \\
\text { content } \\
\text { (mg/0.5ml) }\end{array}$ & $>50$ & 25.21 & 42.1 & 50.55 & 30.5 & 44.10 & 35.68 \\
\hline $\begin{array}{l}\text { Specific } \\
\text { gravity at } \\
15^{\circ} \mathrm{C}\end{array}$ & 0.937 & 0.923 & 0.952 & 0.941 & 0.906 & 0.951 & 0.945 \\
\hline $\begin{array}{l}\text { Gum } \\
\text { content } \\
\text { (mg/100ml) }\end{array}$ & $\begin{array}{l}\text { Nil or very } \\
\text { low }\end{array}$ & 6.0 & 9.20 & 8.66 & 8.41 & 6.72 & 7.60 \\
\hline $\begin{array}{l}\text { Distillation } \\
\text { Range }\left({ }^{\circ} \mathrm{C}\right) \\
\text { IBP } \\
50 \% \\
\text { FBP }\end{array}$ & $\begin{array}{l}200-210 \\
240-260 \\
280-300 \\
\end{array}$ & $\begin{array}{l}94.0 \\
163.0 \\
257.4\end{array}$ & $\begin{array}{l}188.0 \\
260.0 \\
314.2 \\
\end{array}$ & $\begin{array}{l}161.4 \\
205.4 \\
297.4\end{array}$ & $\begin{array}{l}190 \\
>300 \\
>300 \\
\end{array}$ & $\begin{array}{l}175.8 \\
190.4 \\
253.2 \\
\end{array}$ & $\begin{array}{l}180 \\
219.6 \\
305.6 \\
\end{array}$ \\
\hline
\end{tabular}

\section{Quality Parameters}

Quality parameters considered in this work are those relevant to the anti-fouling and dispersing action of solvent, namely: Aromatic content, specific gravity, gum content and distillation range (Table 3). The aromatic content, specific gravity and gum content for specific samples, are presented as follows: $25.21,0.923$ and 6.0 for 
operational wash oil, sample $A ; 35.68,0.945$ and 7.60 for wash oillight cycle oil blend, sample $F$ and $44.10,0.951$ and 6.72 for wash oil/heavy residue blend, sample $E$.

The results from the blend samples $E$ and $F$ showed great improvement over the operational wash oil, sample $A$ in terms of aromatic content and specific gravity, and seems more consistent with the international standard than others. But the very high aromatic content and low gum content of the wash oill heavy residue blend, sample $E$ would enhance its dispersing and antifouling action on polymeric fouling more adequately than the operational wash oil, sample A

\section{Cost Effectiveness}

The use of wash oil/heavy residue blend, sample $E$ would be more cost effective compared to that of wash oil/light cycle oil blend, sample $F$, since the heavy residue, sample $C$ is obtained locally within the EPCL plant (as cracked hydrocarbon by-product). This is rather unlike the light cycle oil, sample B obtainable from outside the EPCL plant.

\section{CONCLUSION}

The heavy residue, sample $C$ remains the most suitable blending solvent for this work, considering its high aromatic content and its availability within the plant. Although, the wash oil/heavy residue blend, sample $E$ did not absolutely meet the international standard quality for wash oil, but it still remains the best option, on comparing its quality parameters with that of the operational wash oil, sample $A$, hence would reduce polymeric foulings to optimum level in the cracked gas compression (CGC) system.

$\begin{array}{ll}\text { NOMENCLATURE } \\ \text { EPCL } & \text { Eleme Petrochemicals Company Limited } \\ \text { CGC } & \text { Cracked gas compression } \\ \text { PCC } & \text { Process gas compression } \\ \text { NGL } & \text { Natural gas Liquid } \\ \text { ASTM } & \text { American society for Test and Materials. } \\ \text { R } & \text { Alkyl or Aryl group } \\ \text { IBP } & \text { Initial Boiling Point } \\ \text { FBP } & \text { Final Boiling Point } \\ \text { W } & \text { Weight }\end{array}$

\section{REFERENCES}

Bangerter, S., 1990. Cracked Gas Compression. NALCO-Chemie Gmbli. PP.6-10

Barnard, P.C., 2000. Centrifugal Compressor Fouling, Understanding, Mitigation and Cleaning. Deepdone Consulting Limited with NALCO / Exxon U.K. PP. 20-25

Bangerter, S and Kranz, R., 1993. Cracked gas compression. Oil and Gas, European magazine volume 4.P.4

Coker, A. K., 1994. Selecting and sizing process compressors. A.K.C Technology. Journal of Hydrocarbon processing, 2: $39-47$

Hercules Incorporated, 2000. Gas compressor fouling. A division of Hercules Incorporated. PP. 3-4.

Okehs, J, K., 2000. Fouling Control and Monitoring in Process Gas Compressor -The EPCL Experience. Nigerian Society of chemical Engineers Technical lecture series. PP. 2-5

Operations Manual, 1993. Chiyoda, Yokohama, Japan. pp. 40-48

Wiehe, 1. A., 2001. The chemistry of Petroleum Fouling. Copyrighted by soluble solutions. American Institute of chemical Engineers Session on Tutorial (Unpublished) PP. 1-6 